\title{
DESCRIPTIONS OF TWO GIANT RATS FROM NEW GUINEA, PRESENTED TO THE BRITISH MUSEUM BY THE HON. WALTER ROTHSCHILD, F.R.S.
}

\author{
BY OLDFIELD THOMAS.
}

(Published by permission of the Trustees of the British Museum.)

\section{Uromys rothschildi sp. n.}

A very large.wholly black-tailed species allied to $U$. anak.

Size rather less than in $U$. anak. General colour above blackish grey, appearing at first sight much darker than in anak, but this would seem to be due to the fact that the type is almost wholly in fresh unbleached pelage, while that of anak is, with the exception of a few patches, in a bleached and reddened condition. These few patches are, as stated in the original description, of a dark grizzled grey, made up of mixed black and white, and this colour is closely similar to that of $U$. rothschildi; the latter appears, however, to be rather more heavily washed with black on the crown and fore-back. Under-surface dull soiled whitish, not sharply defined laterally, the basis of the hairs pale slaty, except on the throat and a small patch on the middle of the chest, where they are white to the roots; chin dark brown. Ears short, ronnded, naked, brown. Hands and feet blackish brown above, the digits practically naked. Tail with its basal two inches hairy, blackish; the remainder naked, finely scaled, black to the tip. Mammae, $0-2=4$.

Skull essentially rather smaller than that of $U$. anak, but owing to its longer muzzle the total length would be about the same. Nasals very long, narrow, their broadest point in front, then narrowing and again broadening at their middle; not extremely narrowed behind. Supraorbital edges well ridged; a prominent sub-postorbital process present. Diastema very long, with the palatal foramina situated far forwards, their posterior end in front of the anterior end of the anteorbital canal; the distance from their hinder end to the front root of $\mathrm{m}^{1}$ decidedly greater than that from their front end to the henselion. Molars smaller than in $U$. anak.

Dimensions, taken on skin : Head and body, 350 ; tail, 355 ; hindfoot (wet), 68 ; ear (wet), 23. Skull, gnathion to basilar suture, 58 ; zygomatic breadth, 34 ; nasals, length, 28 , anterior breadth, $7 \cdot 4$, middle breadth, 65 ; interorbital breadth, $10 \cdot 5$; breadth between parietal ridges, 18.2 ; height of muzzle behind incisors, $14 \cdot 2$; height of crown from alveolus of $\mathrm{m}^{1}, 19.5$; palatilar length, $37 \cdot 6$; diastema, 23 ; palatal foramina, $6.5 \times 3.4$; upper molar series (crowns), 12.8 .

Hab.: Rawlinson Mts., S.E. German New Guinea.

Type: Adult female, B.M. No. 12. 1.31.2. Collected by C. Keyser, and presented by the Hon. Walter Rothschild, F.R.S.

This fine species, which I have named in honour of the donor of the two valuable rodents now described, is undoubtedly most nearly allied to $U$. anak, but differs by the cranial details above described. $U$. validus and the other related New Guinea species are smaller, and have yellow tail-tips. U. multiplicatus Jent., a species based on a young specimen, came from Humboldt Bay, and is therefore not likely to be the same. All this group of Uromys have the "multi-plicate" strncture of the palate used as a distingnishing character by Dr. Jentink. 


\section{Mallomys hercules sp. $\mathrm{n}$.}

Larger than M. rothschildi, nasal and anteorbital region more swollen.

Size very large ; one of the largest of the Muridae. Fur long, ordinary hairs of back about $35 \mathrm{~mm}$. in length, the longer bristle hairs attaining nearly $70 \mathrm{~mm}$. General colour dark grey ("slate colour"), not very dissimilar to that of $M$. rothschildi, with the exception that the projecting ends of the long bristle hairs are whitish instead of black. The ordinary fur is slaty for most of its length, then browner, blackish at tip, but with commonly a glossy whitish subterminal band. Under-surface cream-buff, nearly white on throat, inner side of forearms, and in inguinal region; in M. rothschildi the under-surface is more or less greyish. Chin brown. Head uniformly brownish, the area round the eyes a little darker. Ears short, naked, brown, the fur of the head round them rather greyer than the rest. Hands and feet brown above, the metapodials well haired, the digits less so, but the latter not conspicuously scaly above; claws whitish, that of the hallux alone dark brown. Tail long, its basal four inches thickly furry like the body, the remainder practically naked; scales small (about 7 to the $\mathrm{cm}$.), transversely oval, not pointed behind, their posterior edge turned upwards, two or three minute hairs, about a scale in length, growing from behind each of them. (In Hyomys the scales are larger -4 to the $\mathrm{cm}$.- and pointed posteriorly, the points projecting prominently ontwards.) In colour the tail is black proximally, and rather lighter terminally, but not sharply bicolor as in Hyomys.

Skull, as compared with that of M. rothschildi, considerably larger, and with very much broader muzzle and nasals. Anterior part of supraorbital edges even more inflated than in rothschildi, and the upper part of the ascending process of the maxillary-external to the exceedingly slender premaxillary frontal processes -also inflated. Cranial ridges well developed throughout. Palatal foramina more open.

Teeth essentially as in $M$. rothschildi, but there is a median re-entrant angular notch on the hinder side of the middle back cusp of $\mathrm{m}^{1}$ and $\mathrm{m}^{2}$; the small anteroexternal cusp of $\mathrm{m}^{2}$, found in $M$. rothschildi, is here absent.

Dimensions of the type, measured in skin: Head and body, $470 \mathrm{~mm}$; tail (c), 400 ; hindfoot, s.u. 68 , c.n. 76.5 ; ear, 26 . Skull, occipito-nasal length, 77 ; condylo-incisive length, $75 \cdot 2$; zygomatic breadth, 41 ; nasals, $29.5 \times 13$; least interorbital breadth, 11.7 ; breadth across braincase above meatns, 24; palatilar length, $38 \cdot 3$; diastema, $22 \cdot 2$; palatal foramina, $16 \cdot 2 \times 7$; upper molar series, 18 .

Hab.: Rawlinson Mts., S.E. German New Gninea.

Type: Adult male, B. M. No. 12. 1. 31. 1. Collected by C. Keyser. Presented by the Hon. Walter Rothschild.

This huge rat, so far as its skull is concerned, is the largest member of the subfamily Murinae, though Mus armandvillei Jent. has a longer foot; and of the whole family Muridae it is only exceeded in size by the Philippine Phloeomys. It is readily distinguishable from its congener 1 . rothschildi by the characters given above.

Externally it is curiously similar to Hyomys meeki, also from New Guinea, but Hyomys has scaly digits, and the scales of the tail are of somewhat different shape. The dentitions of the two genera are of course widely different. 


\section{$2 \mathrm{BHL}$ Biodiversity Heritage Library}

Thomas, Oldfield. 1912. "Descriptions of two Giant Rats from New Guinea presented to the British Museum by the Hon. Walter Rothschild, F.R.S." Novitates zoologicae : a journal of zoology in connection with the Tring Museum 19, 91-92. https://doi.org/10.5962/bhl.part.1545.

View This Item Online: https://www.biodiversitylibrary.org/item/22249

DOI: https://doi.org/10.5962/bhl.part.1545

Permalink: $\underline{\text { https://www.biodiversitylibrary.org/partpdf/1545 }}$

\section{Holding Institution}

Natural History Museum Library, London

\section{Sponsored by}

Natural History Museum Library, London

\section{Copyright \& Reuse}

Copyright Status: Public domain. The BHL considers that this work is no longer under copyright protection.

This document was created from content at the Biodiversity Heritage Library, the world's largest open access digital library for biodiversity literature and archives. Visit BHL at https://www.biodiversitylibrary.org. 